\title{
Chapter 4 \\ Inactive Ingredients Used \\ in the Preparation of Ophthalmic Products
}

Some inactive ingredients are used in the preparation of ophthalmic solutions. These ingredients act as diluent or vehicle and are called "excipients." The excipients play an essential role in therapeutic effectiveness by performing one or more of the following functions [1-3]:

1. Adjust concentration and tonicity.

2. Buffer and adjust $\mathrm{pH}$.

3. Stabilize the active ingredients against decomposition.

4. Increase solubility.

5. Impart viscosity.

6. Increase drug permeability and residence time in ocular tissues by enhancing corneal permeability, either by modifying the continuity of the epithelium, altering the lipid/protein components of cell membranes, or changing cell-to-cell junctions.

Often these effects are mediated by the same compounds that act as preservatives or buffers: chelating agents (EDTA); preservatives (e.g. benzalkonium chloride); surfactants (e.g. polyoxol 40); tonicity agents (e.g. NaCl and propylene glycol); and bile acid salts.

\section{References}

1. Divya N, Muthukumaran M, Krishnamoorthy B. A review on recent studies and advances in ocular drug delivery system. Res J Pharm Biol Chem Sci. 2013;3(4):529.

2. Chung S-H, Lee SK, Cristol SM, et al. Impact of short-term exposure of commercial eyedrops preserved with benzalkonium chloride on precorneal mucin. Mol Vis. 2006;12:415-21.

3. Morrison PW, Khutoryanskiy VV. Enhancement in corneal permeability of riboflavin using calcium sequestering compounds. Int J Pharm. 2014;472(1):56-64. 